\title{
Customer Relationship Management to Customer Value \& Customer Loyalty of Fixed Broadband: Study Case on Fixed Broadband Company in Indonesia
}

\author{
Erikson Sianipar, H. Sucherly, Umi Kaltum, Yevis Marty Oesman \\ Padjajaran University, Bandung, Indonesia
}

\begin{abstract}
The increase of fixed broadband penetration can increase a country's economic growth. Indonesian fixed broadband usage density still lags far behind other countries. This condition becomes a great opportunity for operators in marketing fixed broadband products. The different offers and services of each fixed broadband operator in Indonesia will have an impact on the ease of acquiring and maintaining customer loyalty levels. The unstable number of subscribers (unsubscribing/switch to other operator) is increasing year by year. This condition can be caused by customer value perceived by the customer that is inferior because the management of customer relationship management is less good. The method used is descriptive and explanatory. The unit of analysis is the last customer of four broadband operators in Indonesia. Time horizon is cross-sectional, where the research is conducted simultaneously. The survey data are collected from questionnaires to fixed broadband subscribers and through focus group discussions and interviews with managers related to the object study. Data are analyzed descriptively and quantitatively and this research uses quantitative research design using Structural Equation Modeling (SEM). The findings show that the effect of customer relationship management on customer loyalty through customer value is significant.
\end{abstract}

Keywords: customer relationship management, customer value, customer loyalty, fixed broadband

\section{Introduction}

\section{Research Background}

The development of Internet technology is undergoing a very rapid change almost in the whole hemisphere. Survey conducted by the Asosiasi Penyelenggara Jaringan Internet Indonesia (APJII) found that 132.7 million people of Indonesia have been connected to the Internet. The total population of Indonesia itself is as many as 256.2 million people. This indicates a 51.8 percent increase in comparison with the number of Internet users in 2014 ago. Based on surveys conducted by APJII in 2014, there are only 88 million Internet users. In Indonesia, fixed broadband services consist of several fixed broadband service providers named providers/operators:

Ir. Erikson Sianipar, M.M., Doctoral Program of Marketing Management, Padjajaran University, Bandung, Indonesia.

Prof. Dr. H. Sucherly, S.E., M.S., lecturer, Faculty of Economics and Business, Padjajaran University, Bandung, Indonesia.

Dr. Hj. Umi Kaltum, S.E., M.S., lecturer, Faculty of Economics and Business, Padjajaran University, Bandung, Indonesia.

Dr. Hj. Yevis Marty Oesman, S.E., M.P., lecturer, Faculty of Economics and Business, Padjajaran University, Bandung, Indonesia.

Correspondence concerning this article should be addressed to Erikson Sianipar, Faculty of Economics and Business, Padjajaran University, Bandung 40132, Indonesia. 
Indonesia, IndiHome, First Media, Biznet, and MNC Play. The graph shows total fixed broadband subscribers in Indonesia of 3,162,265 subscribers dominated by IndiHome provider of 2,440,362 subscribers ( $77 \%$ of total line in service 2017), followed by First Media with 540,864 subscribers (17\% of total line in service 2017), Biznet of 121,187 (4\% of total line in service 2017), and MNC Play with 59,852 subscribers ( $2 \%$ of total line in service 2017).

In the provision of fixed broadband service providers constrained with high churn-rate potential, churn-rate is the switch of customers to other companies. Churn-rates that occur in fixed broadband provider in Indonesia are as follows:

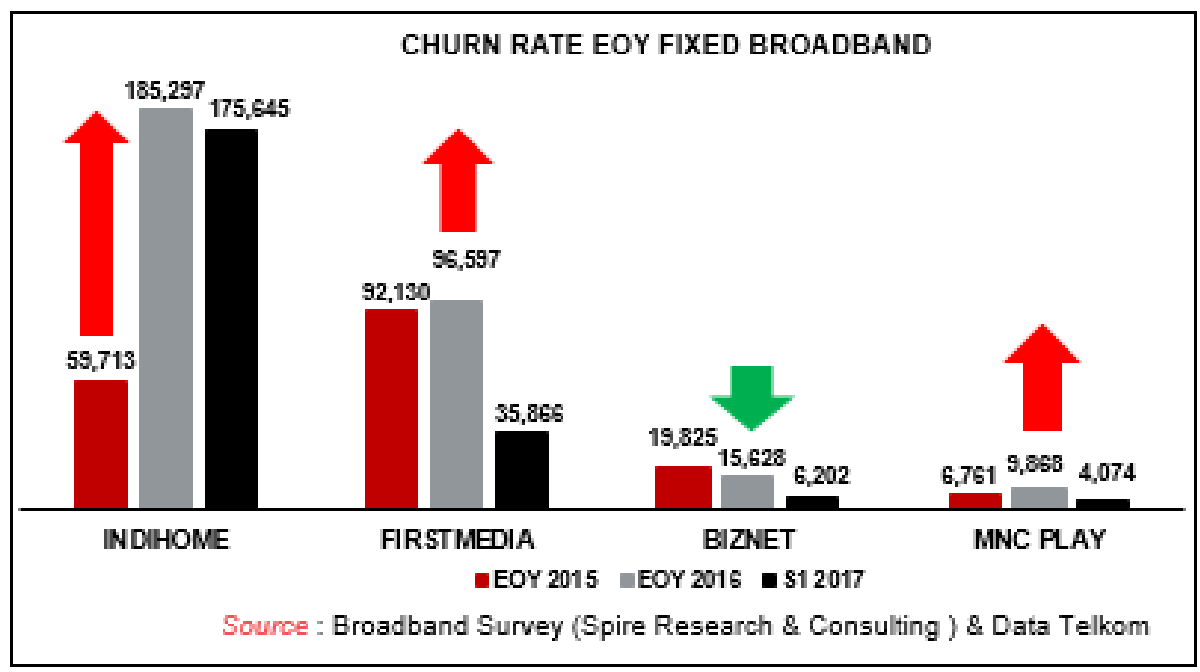

Figure 1. Churn rate 4 top providers fixed broadband in Indonesia.

Figure 1 shows the churn-rate on the four fixed broadband providers. Indihome customer churn occurred in 2015 as many as 59,713 customers, which then increased to 185,297 in 2016 . It was jumped $210 \%$ and improved in the first half of 2017 of 175,645 customers or about $5.2 \%$ of the total churn before. First Media in 2015 has 92,130 customers, but in 2016, it was increasing into 96,597 customers or about $4.84 \%$ and decreased drastically to 35,866 customers due to expansion of network and equipment related to product and service development. Biznet Provider from 2014-2016 has decreased significantly by seeking various promotions with an average decrease of 6,811 subscribers each year, MNC Play Media has increased its churn rate of 3,107 subscribers in 2016 and significantly improved in 2017 by 4,074 subscribers .

Each operator must respond to this churn phenomenon, and the high churn occurrence illustrates that there is a problem with customer loyalty. Customer loyalty is very important for the company. This is confirmed by Louis Columbus in Kotler and Keller (2016, p. 145) stating "Creating loyal customers is at the core of every business". Kuusik (2007) conducted research in telecommunication company in Estonia that concluded there are four factors that influence customer loyalty that is satisfaction, trust, image, and importance of customer relationship.

\section{Literature Review}

Kotler and Keller (2012, p. 145) explained that marketers should build good relationships between companies and customers. The development of customer relationships with the company is a full concern for all marketers in carrying out the marketing function within their business units. This is reinforced by Buttle and 
Maklan (2015), which described the customer relationship management as follows: The role of customer's relation realizes the integration of the company's internal processes with external conditions in order to provide value from targeted customers to generate profit for the company. The most important thing is the history of potential customers embodied in the implementation of technology-based on relationship management.

Key elements in the implementation of management relationships by Donaldson and O'Toole (2002, p. 145) are "Creation of quality products and services, measuring customer satisfaction measures of internalization of human resources management, communicating with more personal customers, targeting customers which is realistic and assesses performance". Strouse (2004, p. 147) stated "Broadband operators interact with customers on every billing schedule so long as customers believe business transactions between them are positive and the billing settlement process is smooth and easy then the relationship will benefit both parties".

Sweeney and Webb (2007, p. 7) revealed that "Customer relationship management dimension is social benefits, psychological benefits, functional benefits". In the Continuity Marketing Program developed loyalty card programs and membership where customers are often rewarded on the basis of loyalty and membership relationships with the company. There are form of rewards or prizes, such as privileged service, gift points, and discounts including other product discounts. One-to-one marketing is aimed at fulfilling and satisfying each customer's needs individually and uniquely. Partnering program is a partnership relationship between customers and companies in order to serve the needs of end users.

Based on the understanding of the above secondary sources, it concluded customer relationship management focuses on managing the relationship between the company and the customer in order to increase the relationship between the two. It is expected that customers can continue to do business with the company, which means an increase in customer loyalty.

Soman and N-Marandi (2010) stated that "The main goal of business is to create value for its customers". Various studies have shown that "Good marketing ability gives companies the ability to create superior customer value" (Guenzi \& Troilo, 2007, p. 98). Companies are always looking for ways to create competitive advantage and deliver value to their stakeholders. Related to the uprooted thing, Sucherly (2007, p. 78) asserted that "Only companies that are able to create superior customer value will win the competition". Further, Kotler and Keller (2016, p. 145) affirmed that the task of every business is to generate customer value by earning profit. Likewise, with broadband operators, they must be able to provide excellent telecommunication services that attract many customers and benefit from it.

The term value is a diverse term used in marketing books. In marketing, its use may be included in various nomenclature and context, with terms "perceived value, perceived service value, perceived customer value, customer value, and others" (Woodall, 2003, pp. 1-42). Lehtonen (2011) stated that "Customer value is a simple equation, namely: customer value = benefits/price". From the formula, customer value can be improved by improving the benefits of the product or service or reducing the price. In addition, it simultaneously raises benefits and prices but the increase in benefits is much higher than price increases.

Kotler and Keller (2016, p. 79) stated that "Customer-perceived value is the difference between the prospective customer's evaluation of all benefits and benefits with all perceived alternative costs". All customer benefits are the perception of monetary value for the economic, functional, and psychological benefits package customers expect from market supply because of the products, services, people, and the image involved. In relation to the image, Kotler and Keller (2016, p. 145) stated "The company can develop a strong and challenging image that encourages the psychological and social needs of its customers". 
Beldona, Morrison, and O' Leary (2006, p. 65) stated that "The perception of value is a trade off between the sacrifices made by the customer and the benefits it receives". Kumar and Reinartz (2006, p. 5) showed that "Customer value is the economic value (in money) of customer relationships with companies declared by their margin or net profit contribution".

G. Barnes quoted by Hurriyati (2010, p. 120), there are four sources of value that can be obtained and perceived by the customers:

(1) Process, optimize business processes and view time as a valuable customer resource.

(2) Persons, employees are authorized and able to respond to customers.

(3) Products/services/technologies, features, and benefits of competitive products and services, reducing productivity disruptions.

(4) Support, ready to help customers who need help.

Based on the above theories, it can be concluded that customer value in the fixed broadband industry pay attention to the difference between the benefits and costs incurred by customers. Benefits perceived by the customers are the benefits of using the product, the benefits due to the ease of service procedure, the benefits due to the authority given by the operator to the service personnel in making quick decisions as well as the support provided by the operator in helping the customer when there is an extra request for the service or installation.

Costs to be incurred consist of the cost of becoming a customer, energy or energy released to obtain the product, the length of time allocated when interacting with the operator, and the cost incurred by the customer when switching to another operator.

Customer loyalty is very important for the company. This is confirmed by Louis Columbus in Kotler and Keller (2016, p. 145) stating "Creating loyal customers is at the core of every business". According to Hermawan (2007, p. 150),

The concept of customer loyalty starts from the era of Leonard Berry, Zeithami, and Parasuraman who said that customer loyalty is identical with customer satisfaction. The next concept continued in the era of Frederic Reicheld where customer loyalty is not necessarily measured by the desire to buy back but more on the level of enthusiasm spreading the good news, referring and recommending the use of products to people.

Hermawan (2007, p. 150) developed a model of customer loyalty with MarkPlus Model called "locking loyalty". The core of locking loyalty concept is an operating model that contains discipline to lock customer loyalty, early and start pre-purchase stage, purchase (purchase), until post purchase (post purchase).

Kuusik (2007, p. 3) who conducted research in Telecommunication Company in Estonia showed "Four factors that influence customer loyalty that is satisfaction, trust, image, and importance of customer relationship". Sucherly (2007, p. 78) conveyed "The lack of customer loyalty in a service business organization is generally pointed out because it is not exactly implementing marketing strategy to achieve competitive advantage". Associated with the discussion of the two experts, this research includes the link between customer loyalty fixed broadband with customer relations and marketing mix.

Griffin (2002, p. 35) stated:

The level of loyalty consists of (1) Suspect, including those who may buy the goods/services company; (2) Prospect, are people who have a need for a particular product/service, and have confidence to buy it; (3) Disqualified Prospect, ie., prospect who already know the existence of certain goods/services, but does not have the ability to purchase the service; (4) First Time Customers, which are consumers who buy for the first time, they are still new customers; (5) Repeat Customers, ie consumers who have purchased a product twice or more; (6) Clients, ie buyers of all goods/services they need and offer 
the company, they buy regularly; (7) Advocates, like clients, advocates buy all the goods/services offered as needed, and make purchases regularly and then they encourage their other friends to buy the goods or services.

The loyalty level of advocates is in line with the statement of Haridasan and Shathi (2011), "One of customer loyalty's behavior is that customers recommend broadband products and services to their friends including buying other products or increasing the number of purchases and service providers which he wore".

Baran, Galka, and Strunk (2008, p. 291) stated "Loyalty relates to customer attachment to a service provider brand based on positive behavioral attitudes and responses". The types of customer loyalty according to Griffin (2002, pp. 22-23) consist of four, namely,

No loyalty, no loyalty, Latent loyalty, and premium loyalties. Loyal customers are an invaluable asset to companies where loyal customer characteristics are repeat purchases, buying out of product lines or services (purchase across product lines), referring others (refers others) and showing immunity from the pull of competition ie not easily influenced by the pull of competition other similar products or Immunity.

Haridasan and Shathi (2011) had researched the issue of loyalty in the field of broadband business in India using dimensions:

- Advocacy: will customers recommend broadband carriers' products and services to their friends?

- Purchasing: Will broadband subscribers buy other products or increase their purchases from used broadband carriers. Other broadband research conducted by Nitzan and Barak (2011, pp. 24-38) used the usage and customer tenure dimensions developed by Verhoef, Neslin, and Vroomen (2007, p. 48).

Another research conducted by Yacout (2010 pp. 2-22) stated "The dimensions of customer loyalty include service recommendations to others, inviting others to subscribe to service providers, becoming the first choice in the future, support continues in the future". Bove and Lester (2009, p. 187) revealed that "Customer loyalty can be measured through elements of credibility, benevolence, and commitment". While Gómez, Arranz, and Cillán (2006, p. 387) explained "Customer loyalty dimension consists of customer trust and commitment to repeat purchase".

Gronhold, Martensen, and dan Kristensen (2000, p. 509) show "Customer loyalty consists of four indicators, namely customer intention to buy back, intention to purchase other products from the same company (cross buying), intention to move to the competitor (tolerance) and intention to recommend the company brand to people other".

Based on the above description, research paradigm can be compiled as follow:

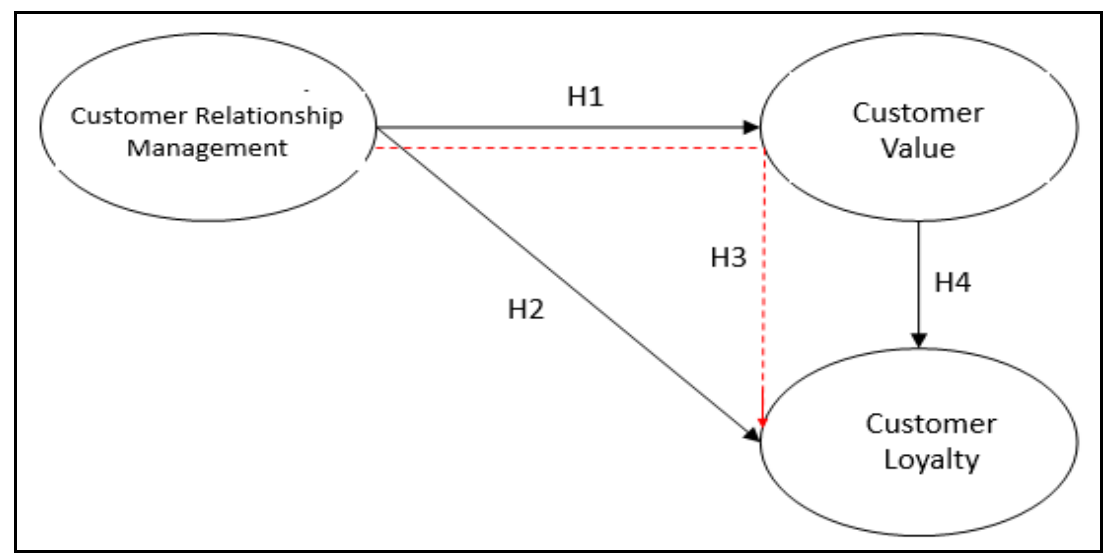

Figure 2. Research paradigm. 
So based on such a research paradigm, the hypothesis is proposed as follows:

Hypothesis 1:

$\mathrm{H}_{0}$ : The influence of customer relationship management on customer value is rejected.

$\mathrm{H}_{1}$ : The influence of customer relationship management on customer value is accepted.

Hypothesis 2:

$\mathrm{H}_{0}$ : The influence of customer relationship management on customer loyalty is rejected.

$\mathrm{H}_{1}$ : The influence of customer relationship management on customer loyalty is accepted.

Hypothesis 3:

$\mathrm{H}_{0}$ : The influence of customer relationship management on customer loyalty through customer value is rejected.

$\mathrm{H}_{1}$ : The influence of customer relationship management on customer loyalty through customer value is accepted.

Hypothesis 4:

$\mathrm{H}_{0}$ : The influence of customer value on customer loyalty is rejected.

$\mathrm{H}_{1}$ : The influence of customer value on customer loyalty is accepted.

\section{Method}

This study uses quantitative research conducted on time horizon (cross section/one shot) in 2017. The analysis approach and the solution technique that used as the analytical tool in this research is Structural Equation Modeling (SEM). The survey was conducted to find out customer perceptions of customer relationship management, customer value, and customer loyalty with 29 questions. The unit analysis in this study is the customer of four fixed broadband operators in Indonesia. Population taken is a group of individuals who ever/are subscribed of fixed broadband products and services of four operators with the largest market share in Indonesia that is Telkom Indonesia, Firstmedia, Biznet, and MNC. Sampling in this research is taken the form of proportional random sampling. The techniques used systematic random sampling that is a systematic random sampling method using the interval in selecting the study sample. The calculation of total samples from each operator was calculated using Slovin formula so that 400 respondents were obtained with proportion of Telkom (309), Firstmedia (68), Biznet (15), and MNC (8). The sample is done in two cities, namely, Jakarta and Surabaya, because the four operators present together in two cities.

\section{Result of Reliability and Validity Test}

The criteria for determining items are valid and have acceptable reliability values based on Table 1 .

Table 1

Criteria Standards Validity and Reliability Instruments Research

\begin{tabular}{lll}
\hline Information & Reliability & Validity \\
\hline Good & 0.8 & 0.5 \\
Acceptable & 0.7 & 0.3 \\
Marginal & 0.6 & 0.2 \\
Poor & 0.5 & 0.1 \\
\hline
\end{tabular}

Calculation of validity and reliability uses software LISREL/AMOS. The result of pre test of validity and reliability with 30 respondents can be seen in Table 2 as follows. 
Table 2

Validity Test Results

\begin{tabular}{|c|c|c|c|c|c|}
\hline Variables & Dimension & Item & $\begin{array}{l}\text { Correlation } \\
\text { coefficient }\end{array}$ & Sig. & Result \\
\hline \multirow{12}{*}{$\begin{array}{l}\text { Customer relationship } \\
\text { management }\end{array}$} & \multirow{3}{*}{ Psychological benefits } & X.1.1 & 0.848 & 0.01 & Valid \\
\hline & & X.1.2 & 0.85 & 0.01 & Valid \\
\hline & & X.1.3 & 0.85 & 0.01 & Valid \\
\hline & \multirow{4}{*}{ Gift-giving } & X.1.4 & 0.86 & 0 & Valid \\
\hline & & X.1.5 & 0.859 & 0 & Valid \\
\hline & & X.1.6 & 0.868 & 0 & Valid \\
\hline & & X.1.7 & 0.844 & 0.02 & Valid \\
\hline & \multirow{5}{*}{ Giving of ease } & X.1.8 & 0.85 & 0.01 & Valid \\
\hline & & X.1.9 & 0.847 & 0.01 & Valid \\
\hline & & X.1.10 & 0.854 & 0 & Valid \\
\hline & & X.1.11 & 0.84 & 0.03 & Valid \\
\hline & & X.1.12 & 0.85 & 0.01 & Valid \\
\hline \multirow{7}{*}{ Customer value } & \multirow{3}{*}{ Benefit } & Y.1.52 & 0.838 & 0.04 & Valid \\
\hline & & Y.1.53 & 0.844 & 0.02 & Valid \\
\hline & & Y.1.54 & 0.867 & 0 & Valid \\
\hline & \multirow{4}{*}{ Korbanan } & Y.2.55 & 0.844 & 0.02 & Valid \\
\hline & & Y.2.56 & 0.867 & 0 & Valid \\
\hline & & Y.2.57 & 0.847 & 0.01 & Valid \\
\hline & & Y.2.58 & 0.851 & 0 & Valid \\
\hline \multirow{9}{*}{ Customer loyalty } & \multirow{3}{*}{ Creation of prospects } & Z.1.59 & 0.847 & 0.01 & Valid \\
\hline & & Z.1.60 & 0.882 & 0 & Valid \\
\hline & & Z.1.61 & 0.864 & 0 & Valid \\
\hline & \multirow{3}{*}{ Customer alignments } & Z.2.63 & 0.844 & 0.02 & Valid \\
\hline & & Z.2.64 & 0.868 & 0 & Valid \\
\hline & & Z.2.65 & 0.861 & 0 & Valid \\
\hline & \multirow{3}{*}{ Customer trust } & Z.3.66 & 0.858 & 0.01 & Valid \\
\hline & & Z.3.67 & 0.81 & 0 & Valid \\
\hline & & Z.3.68 & 0.851 & 0 & Valid \\
\hline
\end{tabular}

Table 3

Reliability Test Results

\begin{tabular}{lll}
\hline Variables & Cronbach Alpha & Information \\
\hline Customer relationship management & 0.795 & Reliably \\
Customer value & 0.805 & Reliably \\
Customer loyalty & 0.809 & Reliably \\
\hline
\end{tabular}

Based on the result of validity test and reliability of instrument above, significant correlation value is that $\mathrm{T}_{\text {count }}$ is greater than $t$ table or the correlation coefficient is greater than 0.3 and the Alpha Cronbrach coefficient is greater than 0.7 . Thus, the questionnaire as an instrument of this study has been able to measure validly and reliably every measurement variable.

\section{Discussion}

The Influence of Customer Relationship Management to Customer Value \& Customer Loyalty

Customer relationship management is hypothesized to affect customer loyalty. The hypothesized calculation of the effect model is obtained using Software LISREL 8.8. 


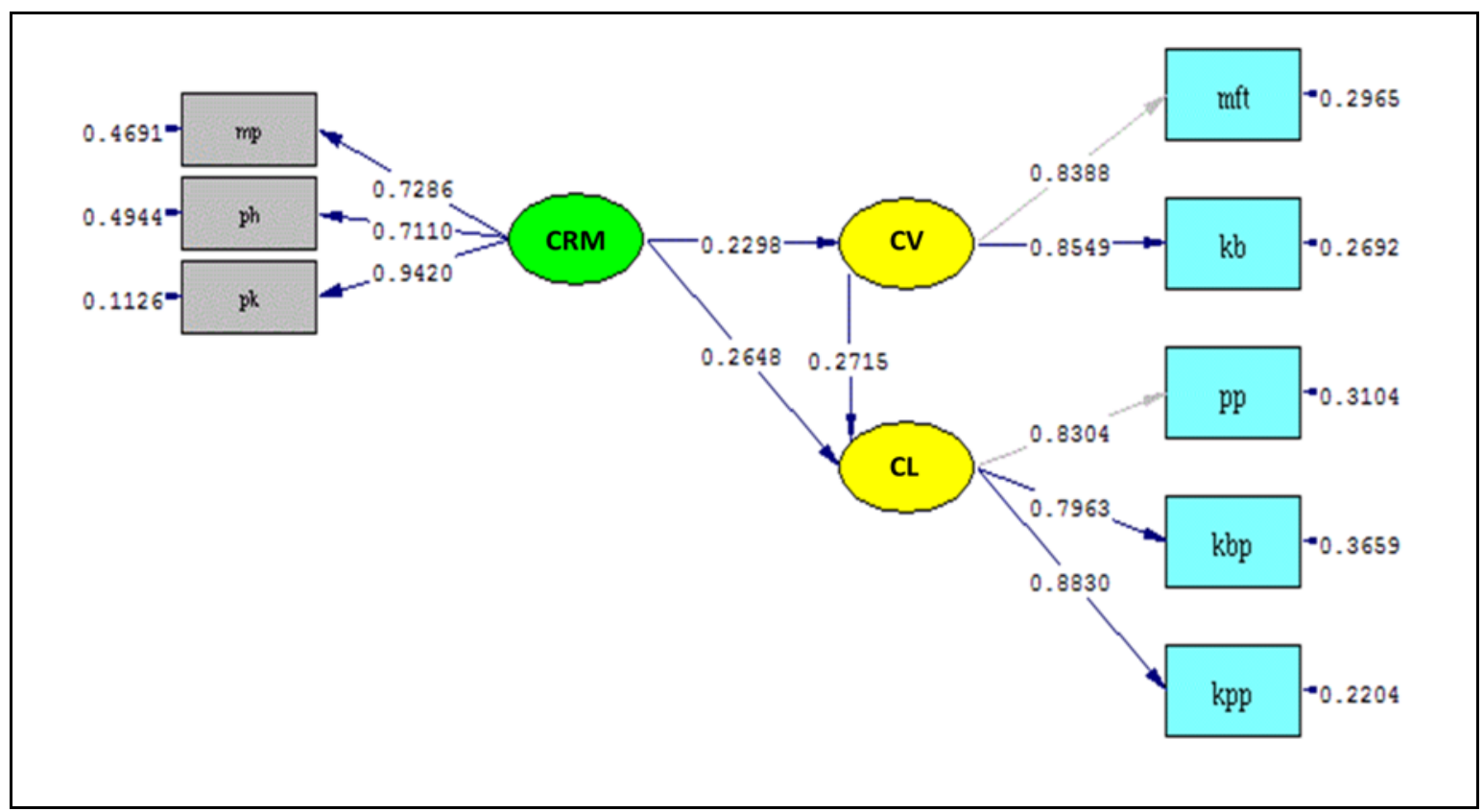

Figure 3. Structural model customer relationship management to customer value and customer loyalty.

The result of statistical test calculation on partial hypothesis testing customer relationship management to customer loyalty is summarized and can be seen in Table 4.

Table 4

Hypothesis Customer Relationship Management to Customer Value \& Customer Loyalty

\begin{tabular}{|c|c|c|c|c|c|c|}
\hline No. & Hypothesis & $\begin{array}{l}\text { Path } \\
\text { coefficient }\end{array}$ & $\mathrm{T}_{\text {count }}$ & $\mathrm{T}_{\text {critical }}$ & Decision & Explanation \\
\hline 1 & $\begin{array}{l}\text { Customer relationship management } \\
\text { affects customer value }\end{array}$ & 0.2298 & 3.2356 & 1.96 & $\mathrm{H}_{0}$ rejected & Significant \\
\hline 2 & $\begin{array}{l}\text { Customer relationship management } \\
\text { affects customer loyalty }\end{array}$ & 0.2648 & 3.9638 & 1.96 & $\mathrm{H}_{0}$ rejected & Significant \\
\hline 3 & $\begin{array}{l}\text { Customer relationship management } \\
\text { affects customer loyalty through } \\
\text { customer value }\end{array}$ & 0.0624 & 2.2208 & 1.96 & $\mathrm{H}_{0}$ rejected & Significant \\
\hline 4 & $\begin{array}{l}\text { Customer value affects } \\
\text { customer loyalty }\end{array}$ & 0.271 & 3.054 & 1.96 & $\mathrm{H}_{0}$ rejected & Significant \\
\hline
\end{tabular}

Based on the calculation, results obtained $\mathrm{T}_{\text {count }}$ for customer relationship management of 3.2356. The value of $t$-test statistic obtained in the region rejected $\mathrm{H}_{0}$ is $\mathrm{T}_{\text {count }}$ that is greater than $\mathrm{T}_{\text {critical }}=1.96(\mathrm{tct}=3.2356>1.96)$, then the decision can be made to reject $\mathrm{H}_{0}$. So, it can be concluded the results of statistical tests show that the management of customer relationship affects the customer value.

While the count for value customer relationship management is 3.9638 , the $t$-test statistic value obtained in the starting region $\mathrm{H}_{0}$ is $\mathrm{T}_{\text {count }}$ that is greater than $\mathrm{T}_{\text {critical }}=1.96(\mathrm{tct}=3.9638>1.96)$, hence can be taken decision to reject $\mathrm{H}_{0}$. So, it can be concluded the results of statistical tests show that the management of customer relationship affects customer loyalty. The magnitude of direct influence customer relationship management on customer loyalty is $(0.2648 \times 0.2648 \times 100 \%)=7.01 \%$. So, customer relationship management gives direct influence if no other variable paid equal to $7.01 \%$ to customer loyalty. 
The third results obtained $\mathrm{T}_{\text {count }}$ value for customer relationship management of 2.2208. Value of $t$-test statistic obtained in the region rejected $\mathrm{H}_{0}$ is $\mathrm{T}_{\text {count }}$ greater than $\mathrm{T}_{\text {critical }}=1.96$. (tct $=2.2208>1.96$ ) and the significance value $p=0.0264<0.05$ then the decision is made to reject $\mathrm{H}_{0}$. So, it can be concluded the results of statistical tests show that the management of customer relationship affects customer loyalty through customer value.

The fourth result obtained $\mathrm{T}_{\text {count }}$ value for customer value of 3.0544. The value of $t$-test statistic obtained in the region rejected $\mathrm{H}_{0}$ is $\mathrm{T}_{\text {count }}$ that is greater than $\mathrm{T}_{\text {critical }}=1.96$ (tct $\left.=3.0544>1.96\right)$, then the decision can be made to reject $\mathrm{H}_{0}$. So, it can be concluded the results of statistical tests show that the customer value affects customer loyalty. The amount of direct influence of customer value on customer loyalty is $(0.2715 \times 0.2715 \times$ $100 \%)=7.37 \%$. So, customer value gives influence directly if there is no other variable paid equal to $7.37 \%$ to customer loyalty.

Based on the research hypothesis, then we obtained research model as follows:



Figure 4. Summary of research model.

\section{Conclusion}

The ability to provide convenience in the form of ease of supplementary services, the convenience of online billing information, and the service office, has a greater role in improving customer value than the development of psychological benefits, and rewarding.

The ability of the company to provide convenience in the form of ease of additional services, the convenience of online billing information, and service offices, has a greater role in improving customer loyalty than psychological benefits, and gift giving. Customer value plays a role in improving customer loyalty.

Increased customer convenience efforts in the form of ease of additional services, the convenience of online billing information, and service offices, have a greater role in improving customer value than psychological benefits, and rewarding, which implies an increase in customer loyalty.

\section{References}

Allen, J., O’Toole, W., McDonnell, I., \& Harris, R. (2002). Festival and special event management (2nd ed.). Queensland, Australia: John Wiley \& Sons.

Baran, R. J., Galka, R., \& Strunk, D. P. (2008). Principles of customer relationship management. Mason: Integral Software Service. 
Beldona, S., Morrison A. M., \& O’Leary, J. (2006). Online shopping motivations and pleasure travel products: A correspondence analysis. Tourism Management, 26(4), 567-570.

Buttle, F., \& Maklan, S. (2015). Customer relationship management: Concepts and technologies. United States: Routledge.

Donaldson, B., \& O’Toole, T. (2002). Strategic market relationship: From strategy to implementation. Singapore: Jhon Wiley \& sons, Inc

Gómez, B. G., Arranz, A. G., \& Cillán, J. G. (2006). The role of loyalty programs in behavioral and affective loyalty. Journal of Consumer Marketing, 23(7), 387-396.

Griffin, J. (2002). Customer loyalty: How to earn it, how to keep it (New and rev. ed.). New York, N.Y.: John Wiley \& Sons.

Gronhold, L., Martensen, A., \& dan Kristensen, K. (2000). The relationship between customer satisfaction and loyalty: Cross-industry differences. Total Quality Management, 11, 509-514.

Guenzi, P., \& Troilo, G. (2007). The joint contribution of marketing and sales to the creation of superior customer value. Journal of Business Research, 60(2), 98-107.

Haridasan, V., \& Shathi, V. (2011). CRM implementation in Indian telecom industry-Evaluating the effectiveness of mobile services providers using data envelopment analysis. International Journal of Business Research and Management (IJBRM), 2(3).

Hermawan, K. (2007). Boosting loyalty marketing performance. Jakarta: Markplus Inc.

Hurriyati, R. (2010). Marketing mix and consumer loyalty. Bandung: Alfabetha.

Irit, N., \& Barak, L. (2011). Social effects on customer retention. Journal of Marketing, November, 75(6), 24-38.

Kotler, P., \& Keller, K. L. (2012). Marketing management (14th ed.). England: Pearson Educational Limited.

Kotler, P., \& Keller, K. L. (2016). Marketing management (15th ed.). England: Pearson Educational Limited.

Kumar, V., \& Reinartz, W. J. (2006). Customer relationship management: A databased approach. New York, N.Y.: John Wiley \& Sons.

Kuusik, A. (2007). Affecting customer loyalty: Do different factors have various influences in different loyalty level? (MA thesis, Tartu University, Estonia).

Liliana, L. B., \& Lester, W. J. (2009). Does "true" personal or service loyalty last? A longitudinal study. Journal of Services Marketing, 23(3), 187-194.

Lohtonen, L. (2011). Economics: Maintaning costumer value. Plup \& Paper Intemational. Febuary.

Soman, D., \& N-Marandi, S. (2010). Managing customer value: One stage at a time. Tuck Link, Singapore: Word Scietific Publishing Co. Pte. Ltd.

Srinivasan, S. S., Anderson, R., \& Ponnavolu, K. (2002), Customer loyalty in e-commerce: An exploration of its antecedents and consequences. Journal of Retailing, 78, 41-50.

Strouse, K. G. (2004). Customer-centered telecommunications services marketing. Norwood: Artech House.

Sucherly. (2007). Marketing strategy in increasing competitive advantage and its implications for customer loyalty. Trikonomika Journal, Faculty of Economics UNPAS, 6(2).

Sweeney, J. G., \& Webb, D. A. (2007). How functional, psychological, and social relationship benefits influence individual and firm commitment to the relationship. Journal of Business \& Industrial Marketing, 22(7), 474-488.

Verhoef, P. C., Neslin, S. A., \& Vroomen, B. (2007). MultiChannel customer management: Understanding the research shopper phenomenon. International Journal of Research in Marketing, 24(2), 129-148.

Woodall, T. (2003). Conceptualising "value for the customer": An attributional, structural and dispositional analysis. Academy of Marketing Science Review, 12(1), 1-42.

Yacout, O. M. (2010). Service quality, relational benefits, and customer loyalty in a non-western context. SAM Advance Management Journal, 75(1), 4-16. 